\title{
Advances and Challenges for Adoption of Activity Based Costing (ABC) by Public Sector: A Comparative Study of Brazil, Colombia, Uruguay and United States
}

\author{
Luís Paulo F Carmo \\ Master Professor of Accounting Department, Uniabeu University, Rio de Janeiro, Brazil \\ Post Code: 26113-400, Itaiara Street, 301, Belford Roxo \\ Tel: 55-21-2104-0466 E-mail: lpfc@ig.com.br \\ Fernando Padovani \\ Doctor Professor of Master's Accounting Program, Uerj University, Rio de Janeiro, Brazil \\ Post Code: 20550-13, São Francisco Xavier Street, 524, $9^{\circ}$ andar, Bloco E, Maracanã \\ Tel: 55-21-2334-0294Ｅ-mail: fernandopadovani@hotmail.com \\ Received: November 7, 2011 \\ Accepted: December 23, $2011 \quad$ Published: February 1, 2012 \\ doi:10.5539/ibr.v5n2p150 \\ URL: http://dx.doi.org/10.5539/ibr.v5n2p150
}

\begin{abstract}
This article aims to evaluate the advances and challenges to the adoption of the activity based costing system (ABC) by the public sector of countries like Colombia, Uruguay and Brazil, always keeping a comparative perspective with the historical experience of the United States. Considering the growing demand of citizens-users of public services in terms of quality, accountability and transparency, and also the convergence of international accounting and management practices, such as convergence on IPSAS by the public sector and the adoption of IFRS in the private sector, encouraged by economic globalization, the study in comparative perspective between different experiences become relevant to public sector organizations, in order to inspire public policies in that direction. The results found by the present research reinforces the conclusions of previous papers (Nunes 1995, IFAC 2000, 2002, 2003, Duarte Martins Mauss and Souza 2008), reaffirming the relevance of the ABC system information for the decision-making process also in the public sector.
\end{abstract}

Keywords: Activity based cost, Public Administration, Public sector, New public management, Accountability, Convergence, Brazil, Colombia, Uruguay, United States

\section{Introduction}

The so called national economies are under a transformation process during the last two decades, in the sense of a stronger productive interdependence among then. Besides the traditional interdependence verified after several decades in the financial markets and also in trade, the high degree of economic interdependence can be noticed now also in the institutional level as well in the productive sphere.

The most visible signs of this trend are the development of regional trade agreements, the growth of the intra-firm trade, the growth and the dispersion of foreign direct investment, the convergence of economic market factors and technologies, as result of the growing importance of global productive networks and supply chains to the local economies. At the institutional level, the spread of regional integration and trade blocs and multilateral regimes all over the World seems to follow the global network economy modus operandi and provide new and effective forms of governance.

All these trends related to a stronger economic productive interdependence point not exactly to the fall of borders but to a lower level of the capacity of control of the territorial national State over the growing number of multiples channels of integration between the different economic regions, in the commercial, financial, productive and corporate level. In this context, not only the governance effectiveness through the traditional public policy is affected, but also the corporate management practices are affected. 
All these transformations can be considered as result and cause of the prevailing dynamics of convergence in the global economy. According to the convergence hypothesis, the greater is the openness and greater is the economic integration to the global economy, stronger is supposed to be the dynamic of convergence, which may drive different aspects such as price levels, market practices, consumption patterns, technological solutions, communication gaps, institutional behavior but also management practices. The logic of the transfer of technologies and techniques follows the investment as well the practices follow the information. The logic of "benchmarking" seems to be present and comprehensive. In this context, also the corporate governance technique follows the spread of the information technologies.

For several decades, according to Hansen and Mowen (2001), companies didn't use to care very seriously about the presence of similar products in oversee markets and much less about questions related to the nature and origin of management control practices in use, because they were separated by geographic distance and protected by market niches. But is was due to some key factors, such as opening markets and international competition, as Wernke (2004, p. 75) reminds us, that organizations are compelled to seek methods to assist in the decision making process, including now an enhanced global rationality, optimal solutions discussed and nurtured in competitive markets, and other essential strategic elements to its permanence in the market segment.

Is this context made of weaker public governance over markets and stronger linkages among economic networks of global range, the market actors decision making process would be affected by a considerable higher degree of incertitude, since, in an interdependent global economy, the new linkages become so complex, even when considering only local markets, always determined by variables from the international business environment.

This is precisely the environment where institutions are valuable and socially demanded, since institutions can provide effective support to bridge the "market failures", understood as rationality failures, in terms of access to information and reduction of transaction costs. And, in a context of retreat of the bureaucratic State institutions, this demand for bridging rational gaps institutions is, each time more in post-modernity, supplied by institutional regimes, public but non-State institutions, market institutions or even by international regimes.

In this context, the economic interdependence in global regional or scale, which enhance and accelerate the movement of economic flows over and under the traditional national and territorial governance boundaries, can be understood also as an inductor factor for reducing costs of organizational activities and processes, due to the increased competition, now on a global scale, updating in global terms the permanent pressure for reducing inefficiencies and waste, but also reducing the transaction costs in market structures itself.

One of the most interesting aspects of this process is that some of the transformations in terms of interdependence and convergence observed in the international economy can also be observed in the public sector management. Since the 1980s, we have been witnessing the emergence of the New Public Management, as a result of the crisis of the traditional "bureaucratic State" and the emergence of the social demands for improvement of the public services supplied, as shown by Lozano and Valencia (2008, p. 85) in the article "Presupuesto y public spending: Secretaría General de Presupuestos y Gastos".

In this sense, this present study aims to access how the economic actors but also the market structures can benefit from adopting management regimes and standards practices, upgrading individual corporate performances and also reducing the transactions costs existing in market structures. The case to be analyzed as a trend of convergence of management techniques will be the adoption and diffusion of the $\mathrm{ABC}$ system, the Activity-Based Costing system in the public sector of emerging economies of Latin America, with special attention to the developments in Brazil, Colombia and Uruguay, always in a comparative perspective with the historical developments observed in the United States.

The quest for higher transparency of public sector spending and better quality of services supplied have widespread over the public sector in all Latin America since the reforms of the 1990s, and several managerial procedures have been gradually incorporated to the State institutions. In this context, the problem of cost determination is commonly central but always elusive to the management of supplied public goods and services, as seems to indicate the several studies, such as Duarte (2002), Cruz (1997), Slomski (2003), Ribeiro Filho (1997), Nunes (1995), BNDES (2000), Félix and Gomes (2008) and Mauss e Souza (2008).

This paper, initially, describes the problem of search to then make the literature review. In the sequence, was dealt with the methodology and the comparative study focusing the challenges of adoption of the $\mathrm{ABC}$ system in the public sector in Latin America, in countries like Brazil, Uruguay and Colombia, always in a comparative perspective with the case of United States. The review of literature will try to highlight the most important and pioneer initiatives, common developments and problems reported. 


\subsection{Research Problem}

This paper aims to discuss one specific aspect of the general dynamic of convergence, also related to the building international patterns and regimes. These trends are assumed as important characteristics of the contemporary economic globalization.

The focus of this work will be set on the convergence of management and corporate governance techniques, a process that is motivated by the expanding global networks of investment and information. These productive global networks seem to be determining the trade patterns, the foreign investment pattern, the technological convergence pattern and also the management techniques patterns.

The present paper wants to contribute to the understanding this process through the analysis of the dissemination of the $\mathrm{ABC}$ system among the public sector management of some Latin American countries (Brazil, Colombia and Uruguay), in comparative perspective with the United States experience, seeking patterns of common challenges for the adoption of this management standard, specially in the public sector management.

The research aims to answer the following question: what are the advances and challenges for adoption of the $\mathrm{ABC}$ system by the public sector of countries like Brazil, Colombia and Uruguay? Which patterns and determinants is its development responding to ?

The answer to this question will indicate in what extent the public sectors of the studied countries have been stimulated by own experiences and positive results or have integrated ready-made management models and techniques.

\subsection{Research Objectives}

The objective of this research paper is to produce insights to those public policies initiatives aiming the reform of public sector management in the sense of enhance the rational performance in the public sector and better cost reducing results. The study will be carried out through the comparative analysis of the implementation and diffusion processes in specific Latin American countries, namely Brazil, Colombia and Uruguay, always considering as reference the historical experience in the United States, considering the convergent and divergent aspects and exploring the possible determinants for its advance of the adoption of $\mathrm{ABC}$ costing system in the public sector, according to the available literature.

\subsection{Methodology}

The methodology used in this research is based on an exploratory comparative study, reviewing the literature about the $\mathrm{ABC}$ system in the public sector of some Latin American countries, order to identify trends and hypothesis.

The research design and the choice of the studied countries are based on the intention to offer economic and economic representativeness and also some degree of geographical and economic variety. Thus, following these criteria, two countries are members of "Mercosur" (Brazil and Uruguay), another country is member of the Andean Pact (Colombia), one is a large and (relatively) closed economy (Brazil), one is a middle size economy (Colombia) and the third is an example of small and open economy (Uruguay).

In this sense, the countries were chosen also in function of the availability of information concerning the adoption of the $\mathrm{ABC}$ system in the public sector. The special case, working as reference to all others, is the United States, where the $\mathrm{ABC}$ system was initially developed and is increasingly being adopted by the public sector.

\section{Theoretical References}

\subsection{Globalization and Convergence}

One of the basic assumptions of the present study is based on the hypothesis that openness and interdependence of local, regional or national economies with the global financial, productive and technological networks produce convergence. Convergence can be noticed in different areas and levels of the economy, such as market factors, prices, practices, technologies and techniques, rules and norms, and even language.

Convergence could be understood, in this sense, as a major dynamic operating in the international economy, in its global networking era, a dynamic resulting, basically, from the contact. Economic contact, recently stimulated by the greater importance of global networks (financial, productive, informational), can redefine aspects such as connectivity, continuity and proximity, which, by their turn, can redefine the own shape of the economic space.

Since "contact" is sharing and also learning, even the cultural perception of distance and the cultural perception of similarities can be transformed by the growing interdependence. Geographical proximity sometimes doesn't mean necessarily to be a determinant to the perception of what is "different", as indicate the researches of Leite (1981) in "cultural affinities of the Executive and the selection of eternal markets in Brazilian companies producing 
manufactured goods" and Freire and Rocha (2003) in the article "The new frontiers: the multinacionalização of Brazilian companies".

Distance is an economic concept and not a "Euclidean" concept, based on the straight line, according to the expression adopted by the World Bank report (2009). The economic distance is related to the access and the connectivity, following an economic space shaped in form of networks, more and more a space of flows and less a space of places (Castells 1999), or a space of circularities.

In this sense, the economic linkages with the Brazilian economy, or the absence of them, make in many cases the neighboring Colombia farther than United States (Freire and Rocha, 2003). It is also what detect Stöttinger and Schlegelmilch (1998) in the article "Explaining export development though psychic distance: enlightening or elusive?" quoted by Freire and Rocha (2003, p. 107), suggesting that "the concept of cultural distance had become less important due to the globalization of markets".

This idea of convergence as a byproduct of interdependence and openness to the global economy is based on the works of neoclassical economic theory of trade. According to this model, the market economy would be based upon the rational logic of specialization as the way to achieve efficiency and productivity. Once fulfilled the requirements of free movement of factors through the economic space, occurring between the different sectors of the same economy or occurring between the different national economies, the rational seek for efficiency through specialization should provoke an equalization of opportunities, a better distribution of factors, an improvement in the optimal allocation and, hence, a general dynamic of convergence.

In this context, the higher is the level of connectivity and unification existing in some given economic space, higher tend to be the degree of specialization, optimal allocation and convergence in that space. Thus, it would be the existence of fragmented and segmented economic spaces, due to institutional, political or infrastructural reasons, that would stimulate the development of local autarkies and economic divergences and imbalances.

In this sense, the contemporary economic global networks seem to be capable of accelerate the economic flows, transporting goods, services, capital, technology and information, enhancing contact, opening space for innovation but also for increased competitiveness, now on a global scale. Both trends seems capable to ultimately represent a factor of pressure and then inductor of changes, pushing organizations is the search for alternatives for reducing costs or improve performance.

The contemporary transformations could be understood as a qualitative new trend, touching the productive base of the economy, where the productive process is each time more organized as productive corporate networks of global reach, and, according to Castells (1999), can be considered as the "basic organizational form" of the global economy. Important indicator of this new basic organizational form is the growing importance of the intra-firm trade.

Its importance in the international trade relations grew from $30 \%$ in 1970 to $55 \%$ in 2000 , according to the World Bank (2009). The sharp resumption of the foreign direct investment in the world economy during the 1990s, especially in the emerging economies, could be understood as another sign of the consolidation of global productive networks, passing from the traditional level of $6 \%$ previous to the 1990 s to $11 \%$ of the capital formation in 2005 , in the World economy. (RICUPERO 2007)

In the managerial environment, this trend can generate a new demand from the citizens-users pressuring the public managers to a better performance and efficiency in the supply of public goods and in the management of public institutions, which may rely on the principle of the lowest cost in conjunction with the highest quality.

Of course, broader forms of contact also generate uncertainty and fear, especially in periods of "great transformations", inspiring, not infrequently, the adoption of protective policies, as a form of reaction against the loose of references and the uncontrolled side effects. During those times is common to arise different forms of localism and autarky, such as the search for local solutions, the protectionism in its several forms and levels, and reliance upon domestic resources, as well the arising of new diffuse demands for "control" in the cultural background.

In the case of the economies focused in the present study, is possible to see some indicators of integration to the global economy. The degree of openness existing in each economy tells us a little about the trade connections with the rest of the World and much more about the degree of importance of the domestic market to each economy. The Table 1 shows the degree of openness of the studied economies.

But when we compare the degree of participation of the foreign transnational corporations in the industry sector, we can have a closer idea about the productive integration to the international productive networks, as can be observed in the Table 2. 


\subsection{The Problem of Efficiency in the Public Sector}

Studies conducted by the Secretary to the Federal Budget, of the Brazilian Government (SOF, 2008: p. 9), pointed out the "need" of a control system based on a detailed cost information structure, as the best support for the management of the public sector. This system could guide the decisions of agencies running public policies but also for the central State bodies of the public administration. This cost-based information system would consist of a "circular flow" focused on the cost information.

This perception expressed in recent policies of some sectors of Brazilian administration seems to extend and deepen the two decades old debate of reform of public administration in the sense of a more rationally managed public sector, in the sense of higher accountability and efficiency of public resource management, as remind us Beckett (2002).

In the same direction, Alonso (1999, p. 45) in the article "Cost in public service" reminds that "the correct calculation of the costs of public services and its publicity are powerful instruments of social control, allowing [...] the evaluation of efficiency of services provided ".

All this effort of reform of the public administration, broadly called as "new public administration", consolidated new priorities and methodologies, all inspired in the almost consensual liberal visions in the 1980s aiming to reduce the size of the State, and, at the same time, to foster a managerial and rational approach to the remaining State institutions.

Other premises were also stimulated the autonomy and the decentralization, as well the greater involvement and participation of the civil society. Beyond the direct privatization, the new policies also seek to promote the indirect administration, based in regulatory agencies and concessions to private suppliers.

All these trends have inaugurated a more diffuse boundary between the public and private spheres, with higher levels of participation and an approach in which public wouldn't mean necessarily state-owned. In Brazil, this new conception was inaugurated in 1995, with the reform plan named "Plano Diretor da Reforma do Aparelho de Estado", following the new constitutional text of 1988, where the "efficiency" where introduced as a formal principle of the public administration.

But the contemporary times seems to aggregate a further demand into the managerial approach of the public administration. As Félix and Gomes $(2008$, p. 2) in the article "Managerial accounting system applied to public administration: A case study on Comlurb" remember, the fiscal crisis occurred recently in Europe and United States are compelling governments around the World to "rewrite its way of thinking the Administration", considering strongly the effort to meet the needs of collectivity in face of the depressed level of available resources, not to mention the increasing demands for transparency, accountability and efficiency.

In this sense, in Spain, Lozano and Valencia (2008, p. 85) in the article "Presupuesto y public spending Secretaría General de Presupuestos y Gastos" remark that all the financial and fiscal turmoil observed recently in the World economy seems to be impacting the priorities of the public administration, urging the affected economies to search for improvement in the use of the depressed resources, trying as much as possible to keep providing quality service, in what could be called an expanded or "reloaded" version of the "New Public Management".

For heavier efficiency demands in public sector administration, tighter cost control seems to be the frequent answer, once efficiency standards depends of the government capacity of checking and vigilance on costs over time, as point out Silva (1999, p. 73) in "Governmental Accounting: a managerial approach".

Even the definition of "efficiency" in the public sector is each time more defined in terms of costs, as remarks Garcia (1997, p. 10) in the article "Evaluation of government action: points to an early conversation", where the efficiency of any scheduled government action is now currently defined as "relationship between products and costs resulting from the completion of a public action".

This microeconomic approach could seem self-evident to the perspective of an individual firm but it is less for a public institution, considering the well-established liberal tradition focusing on the macro level of market structures, where "efficiency" is perceived much more as absence, or, lack of disturbance in the market relations (Saavedra, 2006, p. 10). As Tanzi defines in an influent International Monetary Fund report (IMF 2000), "efficiency" would be the "ability of the State in achieving socioeconomic targets with the least possible distortion of the market and with minimal uptake of available resources".

The relevance of the efficiency to the public sector administration in Latin America is proportional to the weight of the public sector for those economies. 
To assess its not negligible impact, we can analyze the data from Table 3, presenting in percentage of gross domestic product (GDP), the weight of public sector spending in some economies of Latin America. Based on this panorama, Mauss and Souza (2008, p. 3) also advocate the need for implementation of a control system in the public sector focused on the costs incurred.

\subsection{The ABC System}

The ABC system can be defined, following Martins (2006), as a costing method segmented by each specific activity, what seeks to reduce the distortions caused by arbitrary apportionment of indirect costs. However, the utility of the $\mathrm{ABC}$ system is not limited to product cost determination. Other kind of organizations can use this tool to control and organize its activities, dealing with goods and services, in the private or public sector.

The ABC cost system was developed during the mid-1980s in the United States mainly by the managerial efforts performed by corporate research as noticed by Cooper (2009), especially by researches undertaken by corporations such as John Deere, Union Pacific, Tektronix, Hewlett-Packard and General Motors. (Khoury and Ancelevicz, 2000, p. 57)

Documented in several case studies, the ABC system spread among the American and European corporations due to net improvement offered by this managerial tool to the strategic decision-making process (Nakagawa, 1994, p. 70). The cost determination process offered by the $\mathrm{ABC}$ system overcomes the limits of the traditional focus on fixed and variable cost. (Garrison, Noreen and Brewer, 2007)

In this sense, Pamplona (1997) reminds us that the cost determination can be set in function of different corporation segments, lines of production, sectors, or even individual clients or customers. For Martins (2006), with the use of $\mathrm{ABC}$ system by the management can clearly show the cost of each activity which covers all expenses with necessary resources to the organization performance, taking in consideration the wage costs, their social charges, depreciation, energy, materials, facilities etc.

In this sense, it is important to know then what precisely an "activity" is. In several studies and surveys that deal with ABC costing system (PAMPLONA, 1997; KHOURY and ANCELEVICZ, 2000; MARTINS, 2006; CHING, 2006; FÉLIX and GOMES, 2008) the organization activity is understood in a very similar way as defined by Nakagawa (1994, p. 42), as "a process that combines, in an appropriate manner, people, technologies, materials, methods, in its environment" .

Still according to Nakagawa (1994), focusing the cost formation process according to each specific activity as proposed by the $\mathrm{ABC}$ system, it is possible to improve the level of transparency and visibility and better access the contribution of each activity. As Ching (2006, p.99) complements, in the ABC system there is possible to identify the cause-effect relationship, making it possible to control the sources of costs but also identifying the availability of resources required.

Thus, pointed by Kaplan and Cooper (1998), the ABC system can be understood as a response to the inaccuracy of traditional costing system, and as a result of natural evolution of the economy of the firm, each time more composed by increased fixed costs, decreasing of direct labor, high incidence of technological change and information technology, decreasing of importance of the accounting costs and growth in the diversity of products and services.

Concerning the public sector administration, the activity-based costing system (ABC) represents a great opportunity to supply the necessary information to the public administration, once, according to Brimson (1996, p. 41), the activity-based accounting can contribute to change the shape and the dynamics of the organizations, uncovering the relationship between costs and activities, influencing then the decision process, being applicable to the indirect but also direct public administration, as remind us Slomski (2003).

\section{Analysis of Results}

The adoption the ABC system by the public sector in Latin America can be understood as limited and in pioneering phase, despite the significant recent advances. From the experiences observed in Uruguay, Brazil and Colombia, it is possible to identify some common trends.

Following the historical trend observed in the United States, where the pioneer initiatives were implemented by the Armed Forces, the defense administration in the South American countries also were responsible for some experiences, especially in Brazil. In 2004, the Brazilian Army implemented a central cost supervision unity, called SISCUSTOS. But connected to the managerial innovations of transnational corporations, the Brazilian Central Bank (BaCen) has adopted in 2005 a "cost commission" to identify the process of cost formation in its activities.

In Colombia, with its well rooted tradition of modern public administration, the $\mathrm{ABC}$ system has been spread in several agencies and public enterprises, especially those supplying public services as sanitation water and electricity. 
This was result of a decree set by the Superintendent of Public Services determining the implementation of the ABC system in all public service companies. One of the best examples are the efficient "EEPPs", the municipal public enterprises, which had attained a high degree of managerial rationality, and the adoption of ABC systems is present and used to the tariffs determination as well the subsides policies.

The regulatory agencies and concessionaires of the telecommunications sector, such as ENTELSA and Telefonica de Pereira, they are also using the $\mathrm{ABC}$ system to determine the sector tariffs. In the Colombian direct administration, the best example is the system developed in 2001 by the government of the capital district of Bogota, covering three quarters of all district institutions, a process starting with the district public hospitals.

Important contribution has been made by the "Corporación Calidad", a non-profit institute and research center created in 1991 oriented for development of managerial techniques in the public sector. Among the important projects, the institute carries out training programs to the implementation of the $\mathrm{ABC}$ system in public institutions.

In Uruguay, when the wide program of State reform was introduced in the 1990s by the "Comité Ejecutivo para la Reforma del Estado" (CEPRE), the ABC system was highlighted as one of the most important tools to guarantee the managerial approach expected to be implemented in the Uruguayan public sector.

After that, the system became the most important tool to the prices and tariffs determination by the public service suppliers. But the program was abandoned in 2006 and the emphasis on the activity costing approach has decreased.

\section{Final Remarks}

The interdependence between national economies fostered by the global financial and productive networks have increased the level of competition and the importance of learn from the best practices is becoming "vital" to the organizations. This trend has been encouraging the market players to "benchmark" the most successful global management technologies, in order to find alternatives to the fierce competition.

In the search for alternatives to cost reduction and also to the process improvement, corporation but also States and governments are nowadays rethinking their models, trying to improve the general economic environment or only to meet the needs of its citizens, consumers of public goods. The wave of State reform initiated in the 1980s have been stated this values of effectiveness, whose have been over-emphasized in the context of the financial and fiscal crisis of 2008. The control of the costs of the public sector seems more important yet.

In this context, this study indicates that with the use of $\mathrm{ABC}$ costing management information system by the public sector in Latin America is still in halfway or in its early stages. Despite its consensual capacity to promote higher degrees of transparency and accountability of public spending and disseminate a "cost culture" in the public administration, the dissemination seems to depend, as pointed out by previous researches in the area, on the existence of factors such as:

a) qualified administrative staff;

b) reduced levels of populist culture in the public administration;

c) consistent demands from the civil society in terms of transparency, accountability and rationality of public services management;

d) cooperation between academic research institutions and public administration.

In this sense, future studies may verify the level of adoption of Balanced Score Card (BSC) by the public sector of these countries and their possible integration with the $\mathrm{ABC}$ system, to complement the management information that the Government organizations need strategic level for decision-making.

\section{References}

Alonso, M. (1998). Cost in public service, Text for discussion no.31. Brasília: ENAP, Outubro.

Aucoin, P. (1990). Administrative Reform in Public Management: paradigms, principles, paradoxes and pendulums. Governance, 3(2), 115-137. http://dx.doi.org/10.1111/j.1468-0491.1990.tb00111.x

Bagura, Y. (2000). Public Sector Restructuring. Ocassional Paper no. 3. Geneva: United Nations Research Institute for Social Development.

Barzelay, M. (2001). The New Public Management, Los Angeles: University of California Press.

Caulfield, J. (2004). Measuring Autonomy in Social Security Agencies: four countries comparison. Public Administration and Development, 24, 137-145. http://dx.doi.org/10.1002/pad.319

Caulfield, J., \& Larsen, H. (eds.) (2002). Local Government at the Millennium, Berlin: Leske Budrich Opladen. http://dx.doi.org/10.1002/pad.319 
Christensen, T., \& Lægreid, P. (eds.) (2001). New Public Management. The transformation of ideas and practice, Aldershot, Ashgate.

Cooper, R., \& Kaplan, R. S. (1998). Cost and performance, S.Paulo: Futura.

Custeio Baseado em Atividades. (1994). S. Paulo: Atlas.

Félix, C. L., \& Gomes, J. (2008). Managerial accounting system applied to public administration: a case study on Comlurb. RIC-Revista de Informação Contábil, 2(2), 1-18.

Forrssell, A. (2001). Reform Theory Meets New Public Management. CHRISTENSEN: New Public Management, 261-287.

Garcia, R. C. (1997). Evaluation of government action: points to an early conversation, Brasília: mimeo.

Gomes, J. S., \& Salas, J. M. (2001). Management Control: a contextual and organizational approach, S. Paulo: Atlas, $3^{\text {rd }}$ edition.

Gregory, R. (2001). Transforming Governmental Culture: a sceptical view of New Public Management. In: CHRISTENSEN (2001): New Public Management.

Hansen, D. R., \& Mowen, M. M. (2001). Cost Management. S.Paulo: Pioneira- Thomson Learning.

IFAC. (2000). International Federation of Accountants. Perspectives on cost accounting for government: international public sector study. New York: IFAC.

IMF. (2000). International Monetary Fund Report 2000. Washington: IMF.

Khoury, C. Y., \& Ancelevicz, J. (2000). Controvérsias acerca do sistema de custos ABC. Revista de Administração de Empresas, 40(1), 56-62.

Lozano, M. R., \& Valencia, P. (2008). Presupuesto y gasto publico, Secretaría General de Presupuestos y Gastos, Instituto de Estudios Fiscales.

Mauss, C., \& Souza, V. (2008). Cost management applied to the public sector: a model for measurement and analysis of the efficiency and effectiveness of Government. S. Paulo: Atlas.

Nunes, M. A. (1995). Custos no Serviço Público, S. Paulo: Maré.

Ricupero, R., \& Barreto, F. M. (2007). A importância do investimento direto estrangeiro no Brasil. In: ALMEIDA 2007: Internationalização das Empresas Brasileiras. Rio de Janeiro: Elsevier.

Rocha, A., \& Freire, C. (2003). The paradox of cultural distance: the Boticario in Portugal. ROCHA: The new frontiers: the globalization of Brazilian companies.

Silva, L. M. (2004). Contabilidade Pública: abordagem da nova administração pública, S.Paulo: Atlas, 7th ed.

SOF - Secretary to the Federal Budget, Brazilian Government. (2008). Cost Information systems in the Federal Government: guidelines for the development and deployment of methodologies and systems of generation and employment of cost information in federal Government, 2008. Available in < https://www.portalsof.planejamento.gov.br/consultacustos >. access in November 12.

UNCTAD. (2003). The World Investment Report 2003. Geneva: Unctad.

WERNKE. (2005). Rodney Wernke. Activity based costing (ABC) applied to the processes of purchase and sale of goods distributor. Revista de Contabilidade Financeira da USP. S.Paulo, no.38, p. 74-89, May.

Table 1. Degree of Openness of Selected Economies

\begin{tabular}{|l|l|}
\hline country & degree \\
\hline Brazil (in 2005) & $20 \%$ \\
\hline Brazil (in 1995) & $10 \%$ \\
\hline Colombia & $31 \%$ \\
\hline United States & $25 \%$ \\
\hline Uruguay & $25 \%$ \\
\hline
\end{tabular}

Source: Unctad 2006. 
Table 2. Participation of TNC in Industrial Production

\begin{tabular}{|l|l|}
\hline country & participation \\
\hline Brazil & $32 \%$ \\
\hline Colombia & $29 \%$ \\
\hline United States & $11 \%$ \\
\hline Uruguay & $11 \%$ \\
\hline
\end{tabular}

Source: Unctad 2006.

Table 3. Percentage (\%) of GDP (Gross Domestic Product) on Public Expenditure on Goods and Services

\begin{tabular}{|l|l|l|l|l|}
\hline \multirow{2}{*}{ Countries } & Year & 1995 & 2000 & 2005 \\
\cline { 2 - 5 } & 1990 & 17,6 & 17,5 & 17,3 \\
\hline Argentina & 17,8 & 18,8 & 18,6 & 19,2 \\
\hline Bolivia & 18,4 & 21,5 & 21,6 & 22,3 \\
\hline Brazil & 30,8 & 17,7 & 17,9 & 17,8 \\
\hline Chile & 22,9 & 19,9 & 27,4 & 28,2 \\
\hline Colombia & 15,5 & 15,0 & 15,0 & 15,6 \\
\hline Costa Rica & 21,1 & 23,2 & 20,9 & 21,2 \\
\hline Ecuador & 24,8 & 13,9 & 18,6 & 20,0 \\
\hline Guatemala & 14,5 & 15,5 & 13,4 & 13,3 \\
\hline Mexico & 15,3 & 16,0 & 20,5 & 15,7 \\
\hline Paraguay & 12,8 & 15,7 & 17,5 & 16,9 \\
\hline Peru & 16,3 & 18,6 & 18,5 & 19,2 \\
\hline Uruguay & 22,8 & 16,0 & 15,4 & 18,8 \\
\hline Venezuela & 15,8 & & \\
\hline
\end{tabular}

Source: Heston, Summers and Aten quoted by to Saavedra (2006, pp. 10) 